\title{
Implementation of Regional Regulation Number 21 of 2014 concerning the Implementation of Population Administration in the City of Banjarmasin (Case Study of Temporary Residence Certificate)
}

\author{
Nike Purnamawati ${ }^{1 *}$, Jamaluddin ${ }^{1}$, Siswanto Rawali ${ }^{1}$
}

${ }^{1}$ Master of Governmental Science, Faculty of Social and Political Science, Lambung Mangkurat University, J1. Brigjen H. Hasan Basri, Pangeran, District North Banjarmasin, Banjarmasin City, South Kalimantan 70123, Indonesia

DOI: $10.36348 /$ sijlcj.2021.v04i03.007 $\quad$ | Received: 03.03.2021 | Accepted: 20.03.2021 | Published: 23.03 .2021

*Corresponding author: Nike Purnamawati

\section{Abstract}

Population administration is regulated in Law Number 23 of 2006 and has been amended by Law Number 24 of 2013 concerning Amendments to Law Number 23 of 2006 concerning Population Administration. This study aims to determine the importance of communication and information and what factors play a role in implementing the policy implementation of regional regulation number 21 of 2014 concerning population in Banjarmasin City. The research method uses a qualitative approach and descriptive type. The research instrument is the researcher himself. The data collection techniques are observation, interview and documentation. The focus of research is using the theory of policy implementation by Marille S. Grindle. Data analysis used is data reduction, data presentation and verification. The validity of the data used by the data credibility test technique using triangulation to test it. The results show that communication and information are very important elements in the implementation of policies for implementing regional regulation number 21 of 2014. However, there are things that have not been maximally implemented regarding the effectiveness of population administration in the city of Banjarmasin (case study on temporary residence certificates). Judging from the two factors according to Marille S. Grindle, the factor of Content of Policy, because of the six indicators only one has been successfully implemented, namely the Indicator Program Implementer (Policy Implementer). Meanwhile, other indicators do not work because policy implementers do not know who the institutions are involved, there are still people who do not know the perda so they cannot feel the benefits, how the decision is made. There are three dimensions that are indicators of the importance of communication and information, namely: coordination, integration and synchronization. The context of implementation factor, the three indicators have not been successfully implemented. The reasons for this are lack of socialization and direction from the related agency so that the public does not know the perda, does not know the strategy to be implemented, there are still people who are asked for voluntary funds and the absence of the main duties and functions of each agency. It is suggested to the Department of Population and Civil Registration to provide information and meetings to other policy implementers and in providing SKTS services there should already be main tasks and functions. To the Miai River Village to improve services and hold outreach to the temporary immigrants. The RT Head should have the main tasks and functions (Topuction) and need to record and provide information to the immigrant population. To the immigrants, report themselves to the RT and ask about their obligations.

Keywords: Communication and Information, Regional Development, Policy Implementation, Temporary Residence Certificate.

Copyright (C) 2021 The Author(s): This is an open-access article distributed under the terms of the Creative Commons Attribution 4.0 International License (CC BY-NC 4.0) which permits unrestricted use, distribution, and reproduction in any medium for non-commercial use provided the original author and source are credited.

\section{INTRODUCTION}

Population identity is important for society and needs special attention for the government. Every year, the population in Indonesia is increasing, causing many problems such as economic, social, politic, development and welfare problems for society. This is what makes the identity of population important. The purpose of population identity is to provide protection, recognition, determine personal status and legal status

Citation: Nike Purnamawati et al (2021). Implementation of Regional Regulation Number 21 of 2014 concerning the Implementation of Population Administration in the City of Banjarmasin (Case Study of Temporary Residence Certificate). Sch Int J Law Crime Justice, 4(3): 170-181. 
Nike Purnamawati et al., Sch Int J Law Crime Justice, Mar, 2021; 4(3): 170-181

for all population events and other events experienced by society.

Matters regarding population identity are regulated in population administration. In Indonesia, population administration is regulated in Law Number 23 of 2006 and has been amended by Law Number 24 of 2013 concerning Amendments to Law Number 23 of 2006 concerning Population Administration. Article 3 of Law Number 23 Year 2006 states that every resident is required to report population events and important events that has experienced to the implementing agency by fulfilling necessary requirements in population registration and civil registration [1].

One of the problems that government needs to pay attention in population administration is population administration for migrant residents who live temporarily in a district / city. Without realizing it, the presence of immigrants can have a negative impact on population administration. Population data that must be owned by immigrants who live temporarily in an area, especially in Banjarmasin City, is a Temporary Residence Certificate. In Banjarmasin City, the Temporary Residence Certificate is regulated in the Mayor's Decree Number 31 of 2016 concerning Service Standards for the Policy System for Population Document Service of the City of Banjarmasin and the Regional Regulation of the City of Banjarmasin Number 21 of 2014, article 14 paragraph 1 which reads: "Every resident who comes from outside Banjarmasin City area that wants to stay temporarily is given SKTS'[2].

The impact felt if the immigrants do not have a Temporary Residence Certificate, such as the difficulty of finding a job because there are several companies that require employees who are not from the Banjarmasin City area to have a previous Temporary Residence Certificate. Apart from that, another impact is that they cannot open a bank account in Banjarmasin City.

One of the reasons for this regulation because of Banjarmasin City is the capital of South Kalimantan Province which has the largest population compared to other regencies / cities in South Kalimantan, namely until February 2018 it reached 625,481 inhabitants. Where the total male population is 312,740 people and the female population is 312,741 people [3].

One of the Sub-districts in Banjarmasin City which is mostly inhabited by immigrant residents is Sungai Miai Village, because of its very strategic

\footnotetext{
${ }^{1}$ UU Nomor 23 Tahun 2006

${ }^{2}$ Perda Nomor 21 Tahun 2014

${ }^{3}$ Badan Pusat Statistik Kalimantan Selatan, 2018
}

location. According to the Head of the Sungai Miai Village in December 2016, there were 45 migrants in Sungai Miai Village [4]. In addition, in this Sub-district there are two universities, namely the Islamic University of Kalimantan (UNISKA) and the ISPI Pharmacy Academy. So that there are many rental and boarding houses available. However, the large number of immigrants in this Sub-district is not the same as the participation of the community in the ownership of a Temporary Residence Certificate which is actually mandatory for every migrant resident who lives temporarily in Banjarmasin City.

The large number of migrants who do not have this Temporary Residence Certificate (SKTS) can be seen from the data held by the Population and Civil Registration Office of Banjarmasin City. It can be seen that in 2018 the number of migrant residents in Banjarmasin City was 10,236, while migrant residents who had the Residence Certificate (SKTS) in Banjarmasin City in 2018 were 1,446 people [5]. From this data, it can be seen that only a few migrants have a Temporary Residence Certificate (SKTS).

The obligation to have a Temporary Residence Certificate (SKTS) has also been conveyed by the Head of the Population Division of Banjarmasin City, 2013 who said that:

"For newcomers, they ought to bring a letter of introduction of moving from the Office of Population and Civil Registration (DISDUKCAPIL) of their hometown. If they are still not sure whether they have settled in a new place, they only need to report to the RT and sub-district and then arrange a Temporary Residence Certificate (SKTS) at the DISDUKCAPIL of Banjarmasin City. Because according to data in the field there are still many immigrants who use their initial identities and do not report to related agencies. The difficulty of finding a job made Joko, from Solo, Central Java, choose to stay temporarily in Banjarmasin to find work. According to him, because his job is still uncertain, he chose to make a temporary card and has not revoked the files to stay here" [6].

According to Frank Dance in Littlejohn et al., [1], one important aspect of communication is the concept of reducing uncertainty. Communication itself arises because of the need to reduce uncertainty, so that it can act effectively to protect or strengthen the ego concerned in interacting individually or in groups.

\footnotetext{
${ }^{4}$ Data Kelurahan Sungai Miai, 2016

${ }^{5}$ Dinas Kependudukan dan Pencatatan Sipil Kota

Banjarmasin, Desember 2018

${ }^{6}$ Banjarmasinpost.co.id,edisirabu,14Agustus 2013
} 
Nike Purnamawati et al., Sch Int J Law Crime Justice, Mar, 2021; 4(3): 170-181

Based on the problems above, the research title raised by researcher is "Implementation of Regional Regulation Number 21 of 2014 concerning Implementation of Population Administration in Banjarmasin City (Case Study of Temporary Residence Certificate)".

\section{Research Focus}

The research focus is used in research on the implementation of regional regulation number 21 of 2014 concerning the implementation of population administration in Banjarmasin City (a case study of temporary residence certificates), namely using policy implementation theory according to Marille S. Grindle, in this theory there are two factors that influence the implementation of policy implementation. That is:

a. Content of Policy according to Grindle is:

1. Interest Affected

2. Type of Benefit

3. Extents of Change Envision

4. Site of Decision Making

5. Program Implementer

6. Resources Committed

b. The context of implementation according to Grindle is:

1. Power, Interest, And Strategy Of Involved Actor

2. Institution and Regime Characteristic

3. Compliance And Responsiveness

The purpose of this research are to find out and analyze how the communication and information contained in the information system in Banjarmasin City, a case study regarding a temporary residence certificate, and also to find out the content of implementation policy and context for regional regulation number 21 of 2014 concerning the administration of population administration in Banjarmasin City. As a matter of consideration for Banjarmasin City government, especially Sungai Miai Sub-district in possession of a Temporary Residence Certificate (SKTS).

\section{LITERATURE REVIEW \\ Public Policy}

Based on the opinion of Michael and $\mathrm{M}$. Ramesh, 1995 (Nawawi, 2009: 16) there are five stages of the policy process:

a. Agenda setting is a process so that a problem can get attention from the government.

b. Policy formulation is a process of formulating policy options carried out by the government.

c. Decision making, which is a process that chosen by government to take an action or not to take that action. d. Policy implementation is a process in implementing policies in order to achieve results.

e. Policy evaluation, which is a process of monitoring and evaluating the results or performance of a policy.

Furthermore, according to Wahab [2] there are 4 concepts of public policy:

a. Policies are deliberate actions that lead to certain goals.

b. Policy consists of interrelated and patterned actions.

c. The policy is what the government actually does in certain fields.

d. Public policy can take both negative and positive forms.

Furthermore, Agustino [3] said there are several factors that influence the implementation or failure of a public policy, namely:

a. The determinants of policy fulfillment, consisting of: public respect for government authorities and decisions, awareness of accepting policies, legal sanctions, public interest, personal interests and time issues.

b. Determining factors for policy rejection, consisting of policies that are contrary to the existing value system, lack of legal certainty, the existence of a person's membership in an organization and the concept of selective noncompliance with the law.

\section{Policy Implementation}

According to Van Meter and Van Horn, 1975 [4] policy implementation is an action taken by individuals, officials and government or private groups that are directed to achieve the objectives outlined in policy decisions.

As for the model approach in policy implementation, it consists of:

a. Donald Van Metter and Carl Van Horn Model implementation policies

There are six variables, which influence public policy, namely: size and policy objectives, resources, characteristics of the executing agent, attitudes / tendencies (disposition) of the implementers, communication between organizations and implementing activities also the economic, social and political environment.

b. Daniel Mazmanian and Paul Sabatier's Model Implementation Policy

The policy implementation model is called "A Framework for Policy Implementation Analysis". There are three variables that determine it: whether or not the problem is easy to tackle, the ability of the policy to properly structure the implementation 
Nike Purnamawati et al., Sch Int J Law Crime Justice, Mar, 2021; 4(3): 170-181

process and variables outside the law that influence it.

c. George C. Edward II's Policy Implementation Model

George C. Edward III's policy implementation model 1980 [3] known as "Direct and Indirect Impact on Implementation". This model consists of factors of communication, resources, disposition and bureaucratic structure.

d. Implementation of the Merilee S. Grindle Model Policy

According to Merilee S. Grindle, 1980 in her book entitled Politics and Policy Implementation in the Third World [4] that the success of policy implementation is influenced by two variables, namely the content of policy and the implementation environment (context of implementation).

e. Implementation of Policy Model G. Shabbir Cheema \& Dennis A. Rondinelli (1983)

According to G. Shabbir Cheema \& Dennis A. Rondinelli, 1983 (Nawawi, 2009: 148) there are 4 variables that influence, namely environmental conditions, relationships between organizations, organizational resources for program implementation, characteristics and capabilities of implementing agents.

f. David L. Weimer \& Aidan R. Vinning's (1999) Policy Implementation Model

Weimer and Vinning, 1999 (Nawawi, 2009: 151) say there are three variables that influence policy implementation, namely: the logic of a policy, a policy must be in accordance with environmental guidance and capabilities of the implementer.

\section{Temporary Residence Certificate}

The legal basis for Temporary Residence Certificate is Banjarmasin City Regulation Number 21 of 2014 concerning the Implementation of Population Administration in Banjarmasin City. Where in the regional regulation (PERDA) there is in article 14 which reads:

(1) Every resident who comes from outside the city of Banjarmasin who wants to stay temporarily is given an SKTS.

(2) Every resident from outside the region who carries out economic activities and temporarily resides in the area is obliged to deposit a security deposit.

(3) The provisions of the SKTS shall be further regulated in a Mayor Regulation.

Temporary Residence Certificate (SKTS) is a certificate issued by an agency that is responsible and authorized to provide population administration services, namely in this case the Department of Population and Civil Registration which is given to Indonesian citizens who live temporarily in certain cities / regencies has a Regional Regulation regarding the obligation to have the Temporary Residence Certificate. The benefits are as proof of self-report of residents who live temporarily in an area, where the validity period is one year.

As for the use of a Temporary Residence Certificate, namely:

a. It is easy to get help from others.

b. Have an identity as a resident who lives temporarily in an area.

c. Proof of identity of temporary domicile residing in an area.

d. For students outside the region, they can take care of scholarships, make SKCK, make driver's license, and make statements as new students and other needs.

e. Temporary residents can use it to get a job, credit a house, motorbike, car and so on.

\section{RESEARCH METHODS}

In this study, the approach chosen was a qualitative approach with a descriptive research type. Meanwhile, the research location is Sungai Miai Village, Banjarmasin City, because in that Sub-district there are many migrants who live temporarily with various causes.

Furthermore, the subjects or research informants are:

a. Department of Population and Civil Registration, Banjarmasin City

- Head of Sub Division of Population = Drs.M.Yusuf Effendi

b. Head of Sungai Miai Village = Nabehanun Naji, S.AP

c. Head of RT in Sungai Miai Village $=2$ people

- $\quad$ Rosdiana, S.Kom (Head of RT 002)

- $\quad$ Rosmilawaty (Head of RT 005)

d. There are 4 immigrants in Sungai Miai Village

- Mayasari (ULM student from Kintap who does not have an SKTS)

- Damayanti (ULM student from Martapura who does not have an SKTS)

- Tri Anggara Mukti (Uniska students and workers who have SKTS)

- Khusnul Khotimah (works at Transmart Banjarmasin who has SKTS)

Then for the data source used, namely primary data obtained through interviews and direct observation, meanwhile secondary data obtained through document collection, literature study, data and books related to research. 
Nike Purnamawati et al., Sch Int J Law Crime Justice, Mar, 2021; 4(3): 170-181

Data collection techniques were used by means of observation, interviews and documentation, while data analysis used descriptive qualitative data analysis by Miles-Huberman's (1992) version divided into data reduction, data presentation and drawing conclusions or verification. Furthermore, for the selected data validity is using validity test of qualitative research, namely by means of the credibility test with the type of triangulation.

\section{RESEARCH RESULTS AND DISCUSSION General Description}

Sungai Miai Sub-district was formerly Sungai Miai Village which is the main village of the three Subdistricts in North Banjarmasin District. Sungai Miai is one of the villages in North Banjarmasin District. Its area is $+11 \%$ of the area of North Banjarmasin District, which is $179.98 \mathrm{Ha}$ / $1,799 \mathrm{~km}^{2}$. Sungai Miai Village has 2 RWs in charge of 35 RT (PERDA Banjarmasin City No. 23/2010). Until the end of September 2018, the population of Sungai Miai Village was 14,218, consisting of 7,074 men and 7,144 women, with 3,935 family heads. This table can be seen from the population moving in and coming to Banjarmasin City in 2018.

Table-1: Incoming Population In the city of Banjarmasin in 2018

\begin{tabular}{|c|l|c|c|c|c|c|c|}
\hline \multirow{2}{*}{ Num } & \multirow{2}{*}{ month } & \multicolumn{5}{|c|}{ District } & Tot \\
\cline { 3 - 7 } & & B.Sel & B.Tim & B.Bar & B.Ut & B.Te & /month \\
\hline 1. & Jan & 148 & 126 & 180 & 196 & 90 & 740 \\
\hline 2. & Feb & 191 & 150 & 169 & 174 & 99 & 783 \\
\hline 3. & March & 208 & 200 & 175 & 228 & 94 & 905 \\
\hline 4. & Apr & 213 & 194 & 225 & 238 & 103 & 973 \\
\hline 5. & May & 231 & 218 & 206 & 224 & 98 & 977 \\
\hline 6. & June & 133 & 96 & 111 & 124 & 68 & 532 \\
\hline 7. & July & 246 & 227 & 287 & 234 & 159 & 1153 \\
\hline 8. & August & 181 & 241 & 197 & 231 & 133 & 983 \\
\hline 9. & Sept & 125 & 180 & 165 & 209 & 101 & 780 \\
\hline 10. & Oct & 196 & 172 & 213 & 211 & 144 & 936 \\
\hline 11. & Nov & 153 & 127 & 184 & 211 & 74 & 749 \\
\hline 12. & Decem & 153 & 147 & 133 & 177 & 115 & 725 \\
\hline \multicolumn{2}{|c|}{ Tot/district } & $\mathbf{2 1 7 8}$ & $\mathbf{2 0 7 8}$ & $\mathbf{2 2 4 5}$ & $\mathbf{2 4 5 7}$ & $\mathbf{1 2 7 8}$ & $\mathbf{1 0 2 3 6}$ \\
\hline
\end{tabular}

The table below shows the numbers of residents who moved out of 240 people and moved to are 115 people in 2018 to Sungai Miai Village (to make a letter of moving and coming).

Table-2: Population Moving Out in the Miai River Village in 2018

\begin{tabular}{|c|c|c|c|c|}
\hline \multirow[b]{2}{*}{ Num } & \multirow[b]{2}{*}{ Month } & \multicolumn{2}{|c|}{ Gender } & \multirow{2}{*}{$\begin{array}{c}\text { Numbers } \\
\text { M+F } \\
\text { (People) }\end{array}$} \\
\hline & & $\begin{array}{c}\text { Male } \\
\text { (People) }\end{array}$ & $\begin{array}{c}\text { Female } \\
\text { (People) }\end{array}$ & \\
\hline 1. & January & 15 & 11 & 26 \\
\hline 2. & February & 14 & 8 & 22 \\
\hline 3. & March & 14 & 2 & 16 \\
\hline 4. & April & 5 & 4 & 9 \\
\hline 5. & May & 22 & 8 & 30 \\
\hline 6. & June & 12 & 9 & 21 \\
\hline 7. & July & 13 & 9 & 22 \\
\hline 8. & August & 10 & 10 & 20 \\
\hline 9. & September & 17 & 6 & 23 \\
\hline 10. & October & 10 & 14 & 24 \\
\hline 11. & November & 9 & 3 & 12 \\
\hline \multirow[t]{2}{*}{12.} & December & 9 & 6 & 15 \\
\hline & Total & 150 & 90 & 240 \\
\hline
\end{tabular}


Nike Purnamawati et al., Sch Int J Law Crime Justice, Mar, 2021; 4(3): 170-181

Table-3: Incoming Population in Kelurahan Miai River in 2018

\begin{tabular}{|c|c|c|c|c|}
\hline \multirow[b]{2}{*}{ Num } & \multirow[b]{2}{*}{ Month } & \multicolumn{2}{|c|}{ Gender } & \multirow{2}{*}{$\begin{array}{c}\text { Numbers } \\
\text { M+F } \\
\text { (People) }\end{array}$} \\
\hline & & $\begin{array}{c}\text { Male } \\
\text { (People) }\end{array}$ & $\begin{array}{c}\text { Female } \\
\text { (People) }\end{array}$ & \\
\hline 1. & January & 20 & - & 20 \\
\hline 2. & February & - & - & - \\
\hline 3. & March & 6 & 9 & 15 \\
\hline 4. & April & 6 & 1 & 7 \\
\hline 5. & May & 5 & 3 & 8 \\
\hline 6. & June & 1 & 4 & 5 \\
\hline 7. & July & 8 & 5 & 13 \\
\hline 8. & August & 16 & 2 & 18 \\
\hline 9. & September & - & 1 & 1 \\
\hline 10. & October & - & 3 & 3 \\
\hline 11. & November & 12 & 11 & 23 \\
\hline 12. & December & 1 & 1 & 2 \\
\hline & Total & 75 & 40 & 115 \\
\hline
\end{tabular}

Table-4: Population with SKTS in Banjarmasin City in 2018

\begin{tabular}{|c|c|c|}
\hline Num & Month & $\begin{array}{c}\text { Numbers } \\
\text { (People) }\end{array}$ \\
\hline 1. & January & 143 \\
\hline 2. & February & 44 \\
\hline 3. & March & 116 \\
\hline 4. & April & 136 \\
\hline 5. & May & 101 \\
\hline 6. & June & 77 \\
\hline 7. & July & 156 \\
\hline 8. & August & 106 \\
\hline 9. & September & 129 \\
\hline 10. & October & 190 \\
\hline 11. & November & 129 \\
\hline 12. & December & 119 \\
\hline \multicolumn{2}{|c|}{ Total } & 1446 \\
\hline
\end{tabular}

Table-5: Population with SKTS in the Miai River Village in 2018

\begin{tabular}{|c|c|c|}
\hline Num & Month & $\begin{array}{c}\text { Numbers } \\
\text { (People) }\end{array}$ \\
\hline 1. & January & 8 \\
\hline 2. & February & 2 \\
\hline 3. & March & 3 \\
\hline 4. & April & 5 \\
\hline 5. & May & 6 \\
\hline 6. & June & 4 \\
\hline 7. & July & 13 \\
\hline 8. & August & 4 \\
\hline 9. & September & 5 \\
\hline 10. & October & 15 \\
\hline 11. & November & 4 \\
\hline 12. & December & 10 \\
\hline \multicolumn{2}{|r|}{ Total } & 79 \\
\hline
\end{tabular}

\section{Content of policy}

\section{a. Interest Affected}

The results showed that policy implementers still did not know clearly what institutions were involved or which interests were influenced the Temporary Residence Certificate (SKTS) and how the influence of each institution was. Each implementing agency, which should have a clear understanding of the agencies involved, has different knowledge of the institutions involved. Only the Head of the Sungai Miai Village and the Head of RT 002 are aware of the influencing interests in the Temporary Residence Certificate policy.

The interests which influence the Temporary Residence Certificate (SKTS) policy are basically the Population and Civil Registration Service, Sub-district and Head of RT. Certainly, each implementer agencies has their respective duties and functions. Likewise with migrant residents who do not have a Temporary Residence Certificate (SKTS). Because they did not make the Temporary Stay Certificate (SKTS), they did not know the interests that influenced the policy. So that this indicator has not been running optimally.

\section{b. Type Of Benefit}

In implementing the Temporary Residence Certificate (SKTS) policy, the positive benefits to be achieved are there is an orderly population administration for community which is registered in other regional data bases and can be known by natives, also provided not only in one area. So as something happens to the residents it can be known and assisted if it is registered as a temporary resident in the area. 
Nike Purnamawati et al., Sch Int J Law Crime Justice, Mar, 2021; 4(3): 170-181

This was also expressed by all policy implementing agencies. But in reality the benefits have not been achieved. In accordance with the statements of all policy implementing agencies. Because only a few immigrants who live temporarily realize the benefits, they do not make a Temporary Residence Certificate. So that this indicator has not been implemented optimally.

Below can be seen an example of a Temporary Residence Certificate card.

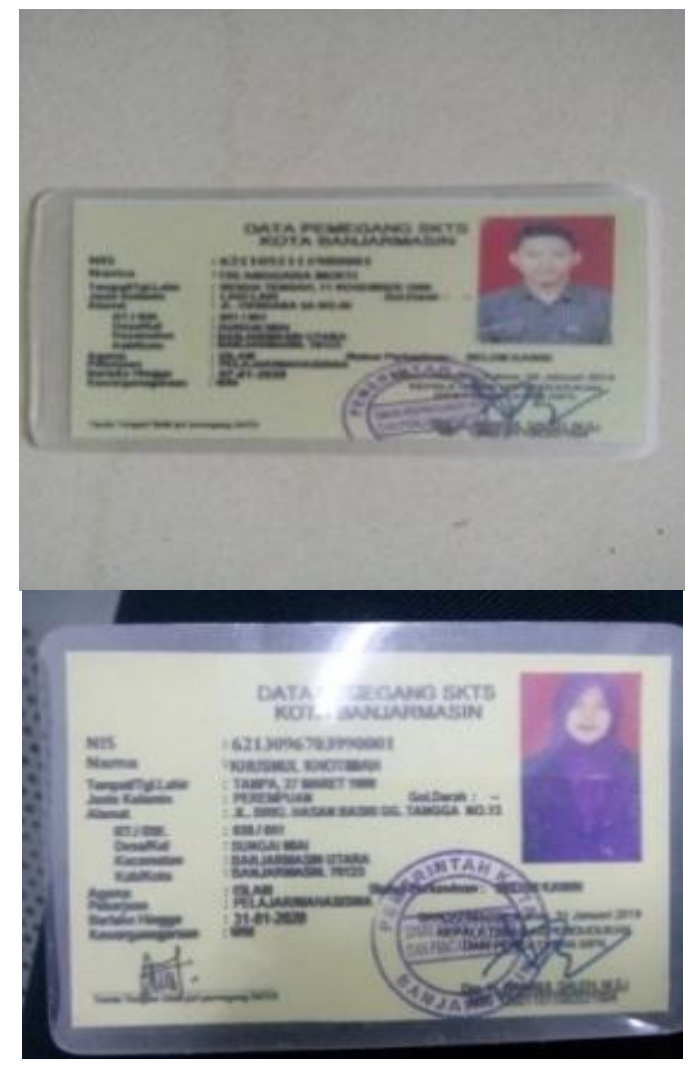

\section{c. Extent of Change Envision}

From the field, the researchers saw that all implementing agencies and temporary migrant population knew the degrees of change that had been achieved. One of the executors of the policy, the Head of RT 005 said that he still did not know the changes because there was no socialization from the Population and Civil Registration Office. Meanwhile, the head of RT 002 said the expected change was an increase in simple and straightforward services. According to him, the change was not significant due to other obstacles.

Meanwhile, according to the Department of Population and Civil Registration, the changes to be achieved in implementing this policy are to open public awareness that wherever they are, they are actually marked with a Temporary Residence Certificate (SKTS). According to the Head of the Sungai Miai Village, the changes he wanted to achieve were that people who were not actually residents of an area would report on their population administration and their existence in that area.

In the presence of this, it should be done with good coordination in each policy implementing agency to produce the same knowledge about the degree of change that would be achieved. The same thing was also expressed by migrant residents who did not have a Temporary Residence Certificate (SKTS), who did not feel the change because they did not have the Temporary Residence Certificate (SKTS). Meanwhile, migrants who have a Temporary Residence Certificate (SKTS) feel the changes after having it according to their needs to use it. So that this indicator has not been going well in accordance with Grindle's opinion.

Together with this can be seen by the staff handling Temporary Residence Certificate (SKTS) at the Department of Population and Civil Registration.

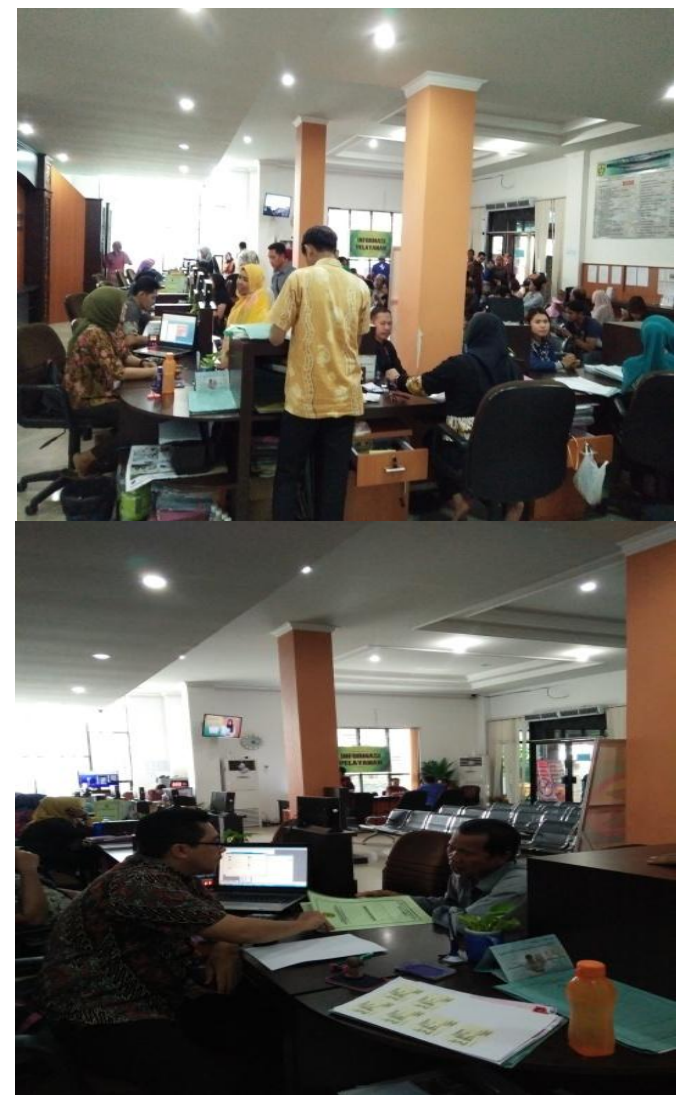

\section{d. Site Of Decision Making}

According to the statement of policy implementers, there are still policy implementers who do not know the location of the Temporary Residence Certificate (SKTS) decision making. As expressed by the head of RT 002 and the head of RT 005. The head of RT 002 said he did not know where this decision was made because of the lack of socialization and coordination among related institutions. Meanwhile, 
Nike Purnamawati et al., Sch Int J Law Crime Justice, Mar, 2021; 4(3): 170-181

according to the Head of RT 005 he also did not know because there never was any socialization from the Population and Civil Registration Service.

Meanwhile, other policy implementers who know from where the decision is made, the Department of Population and Civil Registration said that they know it is the executive and legislature who make decisions. Meanwhile, the Head of the Sungai Miai Village know the location for decision making, namely the Population and Civil Registration Office. Although the two implementing agencies knew, they revealed different things. So it can be seen clearly that there is lack of knowledge for implementing agency in the location of decision making. One of the factors is the lack of coordination between each policy implementing agency. The result showed this indicator was not running yet.

\section{e. Program Implementer}

One of the indicators found in policy implementation is the policy implementer itself. Certainly, policy implementers must know their respective duties clearly. In addition, policy implementers in carrying out their duties must also be competent and capable in their fields and the policy implementers have an adequate number of implementing staff indeed. In implementing the Temporary Residence Certificate (SKTS) policy, the implementing agencies of the policies involved namely the Department of Population and Civil Registration, the Sub-district and the Head of the RT have clearly understood their respective duties. In addition, the staffs who handle policies in each implementing agency are competent and sufficient in number.

For example, at the Department of Population and Civil Registration, the staff knows clearly the requirements for making a Temporary Residence Certificate (SKTS) so residents whose requirements are complete will immediately process their Temporary Residence Certificate (SKTS). In addition, the number of staff is also adequate because there are two staff in the booth who take turns working on it. In Sungai Miai Village the staffs are also competent and adequate. There are two staff members, namely as an administrator and as an operator. Whereas in the RT there is no special staff who handles the Temporary Residence Certificate (SKTS) but only the Head of the RT. Since RT is only tasked with providing a stamp and signature on the form. This is also in accordance with the statement expressed by the migrant residents who made and administered the Temporary Residence Certificate (SKTS). So this indicator can be said have been successfully implemented.

\section{f. Resources Committed}

The resources desired in implementing this policy are surely supporting facilities and infrastructure found in every policy implementing agency. Based on the research results, the desired resources (supporting facilities and infrastructure) owned by all implementers of the Temporary Residence Certificate (SKTS) policy are still inadequate. Completely owned facilities and infrastructure are only owned by the Department of Population and Civil Registration. By reason of this Agency makes and issues Temporary Residence Certificate.

The Sungai Miai Village is quite complete because it has computers, printers, stamps and service counters. Meanwhile, the incomplete implementing agency is the head of the RT, supporting facilities and infrastructure personally. As revealed by residents who live temporarily and make a Temporary Residence Certificate (SKTS), they say that the RT head does not have a computer. As a result, the requested file must be handwritten by the Head of the RT which is then typed by the Sub-district/Village staff. This indicator has not been implemented properly.

Following are the supporting facilities at DISDUKCAPIL to make SKTS.

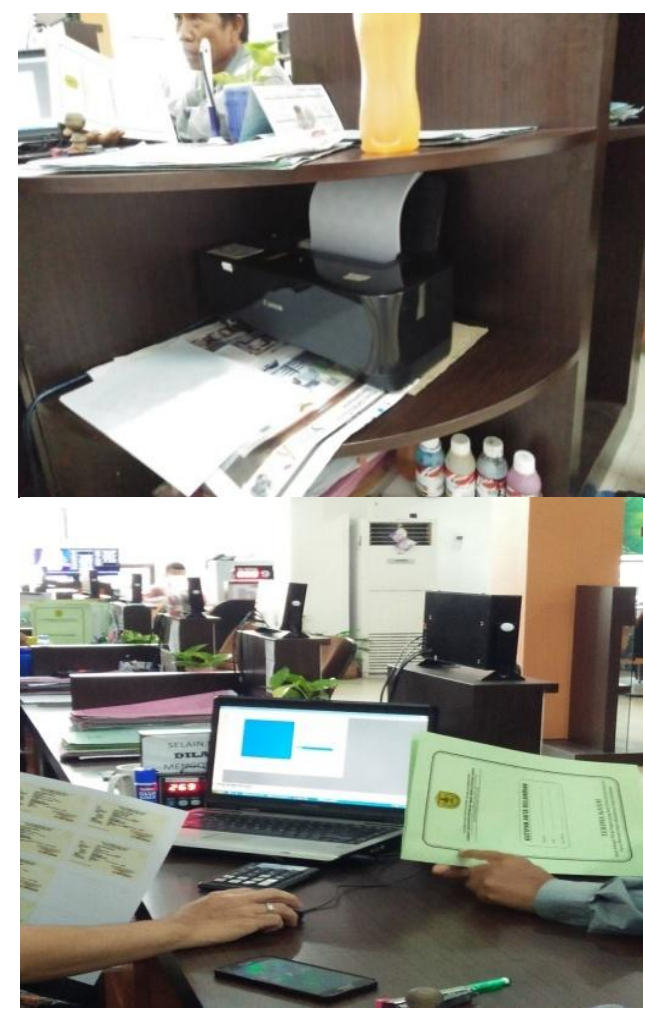

Furthermore, apart from supporting facilities, the application can be seen. 
Nike Purnamawati et al., Sch Int J Law Crime Justice, Mar, 2021; 4(3): 170-181

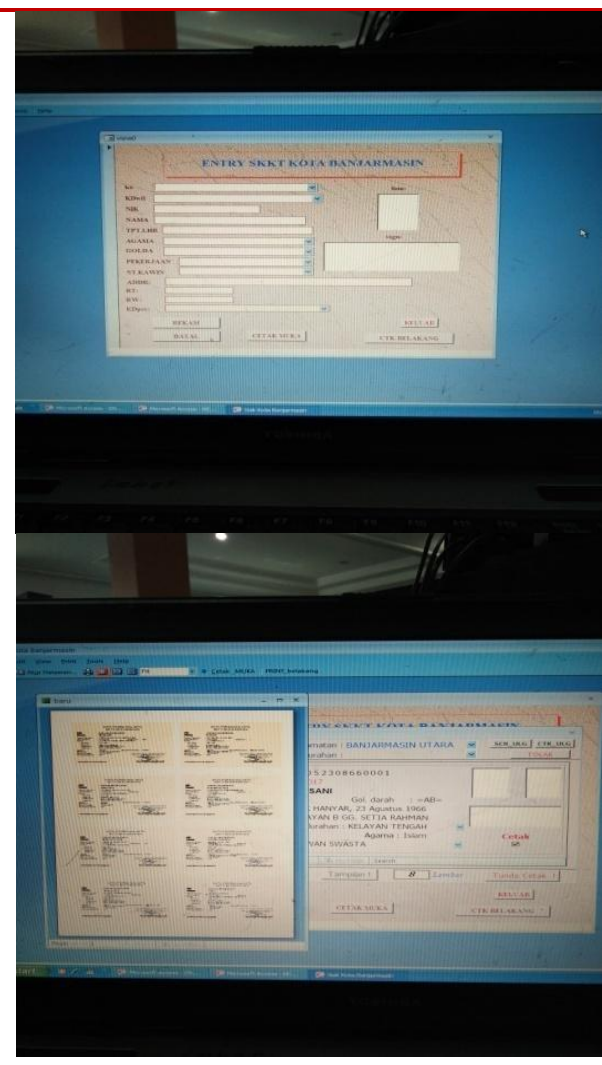

Following are the printouts of the cards and the supporting infrastructure at DISDUKCAPIL.

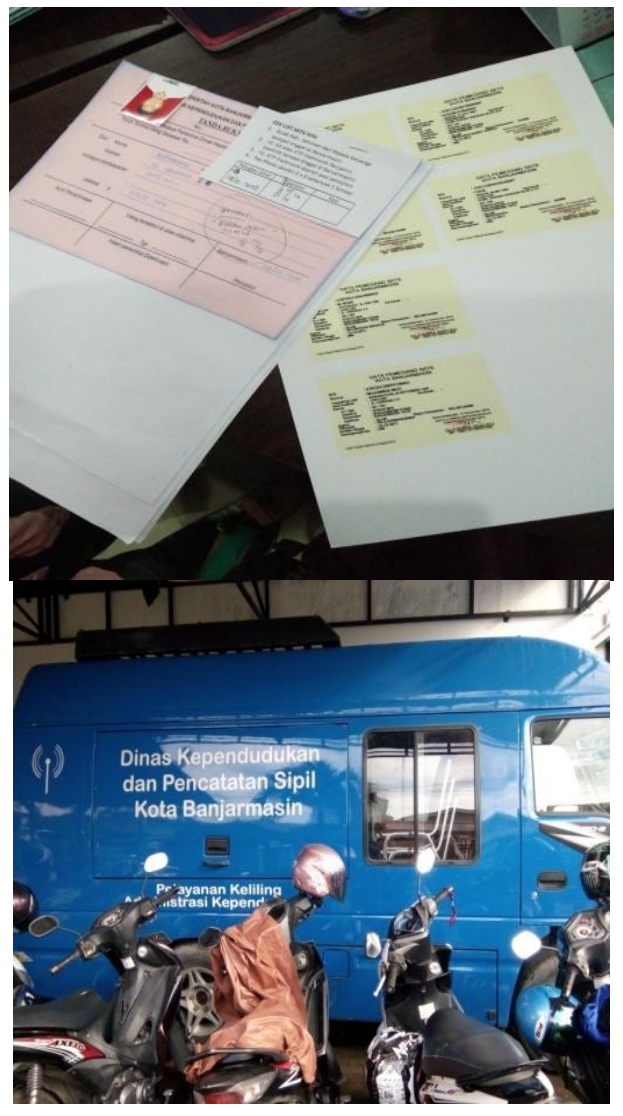

Following are the service counters in Sungai Miai Village.

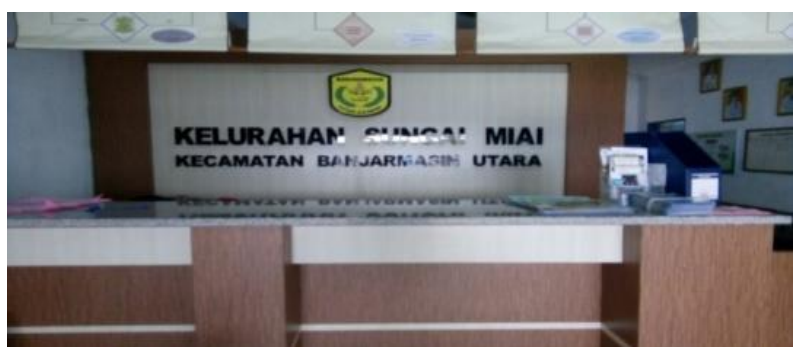

\section{Context of policy}

a. Power, Interest, And Strategy Of Actor Involved

Not all policy implementers have same strategies to increase community participation in this implementation. Only the Department of Population and Civil Registration has a strategy in implementing this policy. The strategy carried out by the Department of Population and Civil Registration is by providing socialization to the public. Meanwhile, in the Subdistrict and RT in Sungai Miai Village, there is no strategy to increase community participation in the ownership of a Temporary Residence Certificate (SKTS). As stated by the Head of Sungai Miai Village and the Head of the RT.

The village head said that he was only an implementer in service, while the strategic direction was to the Department of Population and Civil Registration. In fact, this strategy must be owned by every implementing agency in order to increase community participation. For example, by giving outreach to the campus and making banners about the obligation for temporary residents to have a Temporary Residence Certificate. So that migrant residents who live temporarily know their obligations in population administration. This indicator also has not been implemented.

\section{b. Institution And Regine Characteristic}

According to information from residents of immigrants who have and maintain a Temporary Residence Certificate, they still receive poor treatment from one of the implementing agencies. Where the service that is not optimal is carried out by the Sungai Miai Village. Meanwhile, other residents said that the implementation of the policy was good, but it was troublesome to go through three agencies.

Meanwhile, according to the Department of Population and Civil Registration, Sungai Miai Village and the Head of the RT. The characteristics of the institutions and regimes in power are good enough. As stated by the Head of the Sungai Miai Village. As according to the Head of the Sungai Miai Village, the stage is from the bottom and the person concerned has to pass through the RT first, then to the Sub-district and 
finally the Population and Civil Registration Service. Meanwhile, according to the Head of RT 005, the characteristics are good because there is a form of Temporary Residence Certificate (SKTS). Meanwhile, according to the Department of Population and Civil Registration, the characteristics are good because all processes are related to all implementing agencies. This indicator also has not yet been implemented because there are still some immigrants who administer Temporary Residence Certificates (SKTS) who are not well treated.

\section{c. Compliance And Responsiveness}

The level of compliance and the existence of a response from the policy implementer can be seen in the main tasks of the implementing agency. But in fact all agencies implementing Temporary Residence Certificate (SKTS) do not have a main function in carrying out this policy. The Department of Population and Civil Registration which says that there is no main function because the main function should be stated in the Mayor Regulation. However, this regulation has yet to be made.

Meanwhile, according to the Headman, there is a main function which is then asked to the village secretary and says that there are no main functions and SOP in implementing this policy. The head of the RT also does not have the main function officially given to him. Usually from the Sub-district, he only provides direction and guidance to the Head of the RT.

Meanwhile, according to residents, policy implementers have carried out their duties according to the requirements in the Temporary Residence Certificate (SKTS) form. However, there is an implementing agency, namely one of the RT Heads who asked for voluntary funds on the grounds that as replacement funds for stamp ink and photocopies of the Family Card (KK) and Identity Card (KTP) of the Head of the RT which was used as guarantor as one of the requirements for making it. Even though the processing is free of charge or free. So that this indicator is also not going well according to the opinion of Mariee S. Grindle.

The following form is given to migrant residents who wish to make a Temporary Residence Certificate (SKTS).

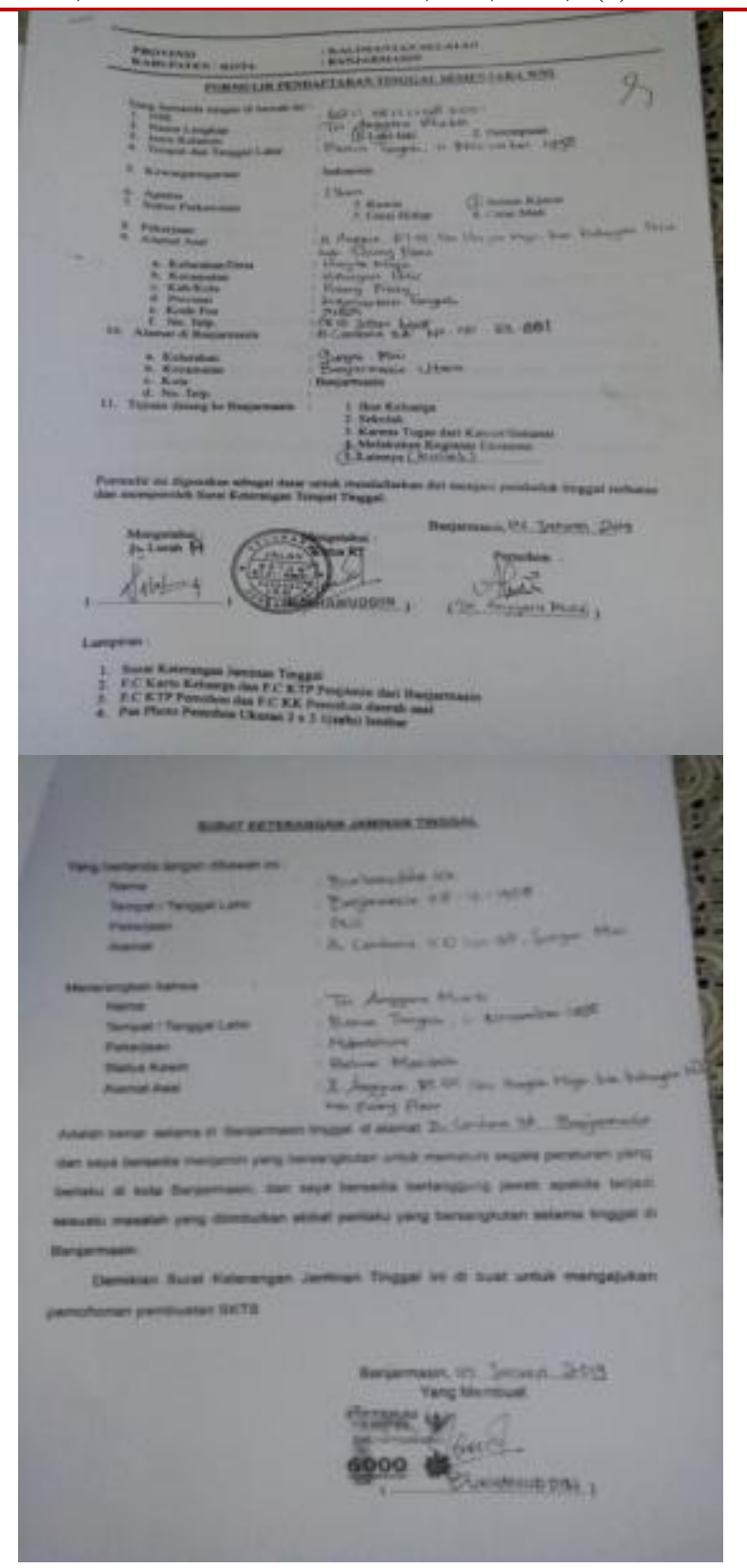

\section{d. Communication and Information Dimensions of Public Services}

This research shows that communication and information are important elements and factors that play a role in the implementation of disaster management policies.

If one examines the importance of communication and information in policy implementation, of course it is to facilitate coordination, integration and synchronization in the implementation of public policy implementation policies in handling temporary residence certificates in Banjarmasin City. 
Nike Purnamawati et al., Sch Int J Law Crime Justice, Mar, 2021; 4(3): 170-181

Communication according to Cook \& Hunsaker [5], aims to improve coordination, share information and satisfy social needs. Thus communication can support the achievement of organizational goals if communication in the organization runs effectively and efficiently.

In policy implementation, the policy implementation model according to Edward III's view in Agustino [3] is influenced by four variables, namely; (1) communication, (2) resources, (3) disposition and then (4) bureaucratic structure. The four variables are also related to one another.

According to Winarno [6], the factors that encourage information ambiguity in public policy implementation are usually policy complexity, lack of consensus on public policy objectives, problems in starting new policies and the tendency to avoid policy accountability.

In managing good communication, effective communication channels need to be built and developed. The better the development of the communication channels that are built, the higher the probability that the orders are being transmitted correctly.

In implementing public policy in Banjarmasin City, the message to be conveyed is the general concept of implementing public policy.

Socialization to other interested parties through program socialization. Socialization is carried out in stages or levels, namely: socialization at the central level, socialization at the provincial level, socialization at the district/city level, socialization at the sub-district level and socialization at the subdistrict/village level.

\section{CONCLUSION}

\section{a. Content Of Policy}

\section{Interest Affected}

This indicator has not been maximally implemented. The reason is policy implementers still do not know clearly the institutions involved or influencing this policy and how the influence of each agency.

\section{Type of Benefit}

This indicator has not been successfully executed maximally. The benefits of SKTS have not been achieved because only a few immigrants have SKTS and are aware of its benefits, so they don't make and own it

\section{Extents of Change Envision}

This indicator has not been implemented successfully. Since not all implementing agencies and the migrant population who live temporarily know the degree of change to be achieved. Each implementing agency has different knowledge in terms of the degree of change to be achieved. It should be with good coordination among all implementing agencies to know the changes.

\section{Site of Decision Making}

This indicator also has not been implemented optimally. By reason of there are still policy implementers who do not know where their decisions are made. It happens due to the lack of coordination and socialization among SKTS implementing agencies.

\section{Site of Decision Making}

Furthermore, it has been successfully implemented. SKTS policy implementers are clear on their duties. In addition, all implementing agencies also have adequate and competent staff in their respective fields.

\section{Resources Committed}

The last indicator is still unsuccessful because the supporting facilities and infrastructure owned by all policy implementers are still inadequate. Completely owned facilities and infrastructure are only owned by the Department of Population and Civil Registration.

\section{b. Context Of Policy}

1. Power, Interest, And Strategy Of Actor Involved

This indicator has not been successfully implemented because only the Department of Population and Civil Registration has a strategy. Meanwhile, in the Sub-district and RT, there is no strategy to increase community participation in SKTS ownership. As a result, there are still many immigrants who are not aware of this policy.

\section{Institution And Regime Characteristic}

The next one has not been successfully implemented either. This is caused by there are migrants who make SKTS less well treated. Meanwhile, other migrants said that it was troublesome to go through three agencies and one of them asked for voluntary funds.

\section{Compliance And Responsiveness}

This indicator has not been successfully implemented because all implementing agencies do not have the main function in carrying out SKTS. The SKTS regulation has not yet been made by the Department of Population and Civil Registration. In addition, every SKTS implementing agency does not have an SOP. 
Nike Purnamawati et al., Sch Int J Law Crime Justice, Mar, 2021; 4(3): 170-181

\section{REFERENCES}

1. Littlejohn, L. F., Devlin, J. J., Kircher, S. S., Lueken, R., Melia, M. R., \& Johnson, A. S. (2011). Comparison of Celox-A, ChitoFlex, WoundStat, and combat gauze hemostatic agents versus standard gauze dressing in control of hemorrhage in a swine model of penetrating trauma. Academic Emergency Medicine, 18(4), 340-350.

2. Wahab, S. A. (2015). Analisis Kebijakan Publik Dari Formulasi ke Penyusunan Model-Model
Implementasi Kebijakan Publik. Cetakan Ketiga. Jakarta : PT. Bumi Aksara.

3. Agustino, L. (2014). Dasar-Dasar Kebijakan Publik. Catakan Kelima. Bandung : Alfabeta.

4. Nawawi, Ismai. (2009). Public Policy Analisis, Strategi Advokasi teori dan Praktek. Surabaya : PMN.

5. Bloisi, W., Cook, C. W., \& Hunsaker, P. L. (2007). Management and organisational behaviour.

6. Winarno, B. (2005). Globalisasi dan krisis pembangunan bagaimana dengan Indonesia. 